\title{
Entre a Pragmática Linguística e a Hermenêutica Filosófica: Hegel e os Desafios DE UMA EsTRUTURAÇÃo Linguística dA EXPERIÊNCIA ${ }^{1}$ \\ Erick Lima ${ }^{2}$
}

\begin{abstract}
RESUMO: Gostaria aqui de contribuir tanto à compreensão das concepçôes de Hegel acerca da linguagem quanto para uma apreciação da interlocução entre essas concepçōes e alguns desenvolvimentos na filosofia pós-hegeliana. O tema mais geral consiste em evidenciar os esforços de Hegel para estabelecer uma relação intrínseca entre experiência e linguagem. Primeiramente, tomando como ponto de partida questôes diretivas da epistemologia moderna, gostaria de compreender traços da concepção hegeliana de linguagem no contexto de uma tematização intersubjetivista da validade objetiva (1). Em segundo lugar, gostaria de refletir sobre a relação entre metafísica inferencial e cogniçáo (2). Finalmente, depois de tentar respaldar a tese de que Hegel antecipa a questão de uma tensão entre o gramatical e a historicidade do léxico (3), mostro como a conexão entre a guinada ontológica na hermenêutica e a doutrina hegeliana da sentença especulativa conduz à experiência do inacabamento linguístico do sentido poético (4).
\end{abstract}

PALAVRAS-CHAVE: Linguagem. Epistemologia. G.W.F Hegel. Pragmática. Dialética. Hermenêutica.

\section{Hegel e a Linguagem: UMA APROXimaÇÁo}

$\mathrm{Na}$ introdução à Fenomenologia, Hegel menciona que a atuação contra as "representaçóes contingentes e arbitrárias" da teoria moderna do conhecimento tem a ver com a visualização do "[...] uso (Gebrauch) de palavras como o absoluto, o conhecer, e também o objetivo e o subjetivo, e inúmeros outros cuja significação (Bedeutung) é pressuposta em geral como familiar." (HEGEL, 1970, 3, p.70). Declaraçóes como essa, quando consideradas à luz da "gênese fenomenológica do espírito", o "nós" das pretensôes epistêmicas e normativas em "mundos da vida" compartilhados, funcionam como inspiração para a interpretação da Fenomenologia enquanto antecipando a guinada pragmática na semântica. A plausibilidade de uma interpretação pragmáticosemântica e inferencialista dessa obra depende da ideia de que, nela, a

\footnotetext{
${ }^{1}$ http://dx.doi.org/10.1590/S0101-31732016000300005

${ }^{2}$ Professor Adjunto no Departamento de Filosofia da Universidade de Brasília. Professor Efetivo do Programa de Pós-Graduação em Filosofia da Universidade de Brasília (PPGFIL-UnB). Bolsista Produtividade em Pesquisa do CNPq (categoria 2). E-mail: callima_er@hotmail.com.
} 
prática humana seja tecida pelo significado intersubjetivamente mediado de conceitos, ou seja, que o emprego de conceitos pressuponha náo a reação a dados não conceituais, mas um inferencialismo semântico (BRANDOM, 2002). Na presente oportunidade, partindo de consideraçóes de Hegel sobre a linguagem, pretendo contribuir à tematização, na filosofia de Hegel, de alguns temas relacionados a essa leitura, bem como de alguns potenciais inauditos de uma relação a Hegel, pela via da linguagem.

\section{Linguagem e a Dimensão Intersubjetiva da Validade}

Nos Prolegomena, Kant deixa claro quão diretivo é, para seu programa epistemológico, o projeto de superar a refutação humiana da noção enfática de objetividade do conhecimento empírico. Em boa medida, "[...] a solução completa do problema de Hume" (KANT, 1968, IV, p. 313), como reabilitação da pretensão enfática de objetividade, pode ser entendida como uma refutação do nivelamento, cometido por Hume, da noção de experiência (Erfahrung) ${ }^{3}$, refutação que é apoiada na tese de uma reciprocidade entre validade universal e validade objetiva (KANT, 1968, IV, p. 298). Para Kant, por não ter compreendido a experiência em seu caráter publicamente comunicável e intersubjetivamente resgatável em suas pretensóes de validade objetiva; por não ter compreendido que a pretensão de validade objetiva do conhecimento empírico não expressa "[...] apenas uma relação da percepção com um sujeito, mas uma disposição do objeto", que ela exprime, portanto, a "unidade do objeto" (KANT, 1968, IV, p. 298), Hume teria acabado por entender, sugere Kant, a experiência ao modo solipsista de uma simples articulaçáo, válida apenas para o sujeito, de percepçóes cujo acesso lhe é privilegiado, isto é, como simples "juízo de percepção" (KANT, 1968, IV, p. 299).

Mas tal compreensão da base cognitiva para a produção do conhecimento comunicável e dotado de pretensão universalmente resgatável não faz jus ao que Kant - e a física newtoniana - pretende que seja a conexão de eventos a qual se deve chamar de experiência (Erfahrung), da qual "[...] exijo [...] que

\footnotetext{
${ }^{3}$ Nessa compreensão das exigências modernas do que se deva chamar "experiência" reside o que Brandom sustenta ser o compromisso filosófico, herdado de Kant por Hegel, com o caráter normativo dos conceitos, "lógico-estruturais" e "empíricos", o que Brandom entende, na esteira de Wittgenstein, como o que perfaz a exigência filosófica de expor as condiçôes de possibilidade da determinidade de nossos compromissos, responsabilidades e obrigaçóes (BRANDOM, 2002, p. 212, 214). O pragmatismo semântico de Hegel residiria na radicalização dessa compreensão do conteúdo conceitual em termos das operaçōes envolvidas na aplicação do conceito (BRANDOM, 2002, p. 210).
} 
esteja sob uma condição que a torne universalmente válida. Quero, portanto, que, em todo tempo, eu e todos devamos ligar necessariamente a mesma percepção nas mesmas circunstâncias." (KANT, 1968, IV, p. 299). Eis por que, para Kant, caso aceitemos as conexôes subjetivamente válidas de Hume como epistemologicamente relevantes, devemos diferenciá-las categoricamente da experiência (Erfahrung) (KANT, 1968, IV, p. 300) enquanto estofo do conhecimento comunicável e capaz de honrar pretensôes de validade objetiva intersubjetivamente erguidas. "A experiência (Erfahrung) consiste na conexão sintética de fenômenos (percepções) numa consciência, enquanto a mesma é necessária." (KANT, 1968, IV, p. 305). Entretanto, como tal noção de experiência repousa sobre a unidade sintética de uma consciência geral pensada na categoria, abre-se, com essa crítica de Kant a Hume, para a filosofia posterior, a oportunidade de pensar a experiência em sua comunicabilidade, intersubjetividade e estruturação linguística. De fato, seguindo a sugestão de Hume de que os "[...] princípios de associação das percepçóes" talvez pudessem ser visualizados nas estruturas da linguagem corrente (HUME, 2007, p. 19), Kant assevera que as categorias "[...] servem [...] apenas para soletrar fenômenos, a fim de que possam ser lidos como experiência." (KANT, 1968, IV, p. 312). Mais do que isso:

[...] tirar do conhecimento comum os conceitos que não se fundam em nenhuma experiência particular, e que, no entanto, aparecem em todo conhecimento de experiência, do qual constituem ao mesmo tempo a simples forma da conexão, não pressupóe maior reflexão ou compreensão do que tirar de uma lingua as regras do uso real das palavras em geral, e, assim, reunir os elementos de uma gramática (na verdade, ambas as operaçöes estão muito intimamente ligadas). (KANT, 1968, IV, p. 322-323, grifo nosso).

Hegel se revela um leitor muito preciso desse capítulo da filosofia moderna. A Filosofia do Espirito da Enciclopédia pode ser vista como aprofundando a modulação linguística do problema da "dimensão intersubjetiva" da validade. A discussão sobre a linguagem na Enciclopédia, a qual prepara a passagem do "espírito teórico" para o "espírito prático", tem como pressuposto, por isso mesmo, a gênese do espírito como razão a partir da resolução especulativa e intersubjetivista da dialética da autoconsciência, isto é, da produção, através da dialética do reconhecimento, da identidade entre consciência e autoconsciência (HEGEL, 1970, 8, p. 198-204, 225228). Se se aceita que, enquanto fórmula que designa o "verdadeiro conceito de autoconsciência”, "[...] o eu que é um nós, e o nós que é eu”, o espírito 
é "[...] o âmbito do normativo, enquanto produzido pelos processos de reconhecimento mútuo" (BRANDOM, 2002, p. 222), pode-se alcançar um sentido mais amplo para a tese de que, "[...] para o lado de fora", sendo o espírito subjetivo "[...] também a realidade antropológica e conforme à consciência”, seu produto seja, do ponto de vista teórico, a palavra (HEGEL, 1970, 8, p. 237). Com efeito, para Hegel, enquanto o espírito prático, a vontade, em "[...] luta com [...] a singularidade excludente e [...] fazendo contraposição [...] a outras vontades humanas", é marcada por um caráter limitado, "[com a palavra, a inteligência] permanece, em sua exteriorização, completamente junto a si, ela se satisfaz em si própria, prova-se como fim em si, como o divino; e, na forma do conhecimento que conceitua (Form des begreifenden Erkennens), produz a liberdade ilimitada e reconciliação do espírito consigo mesmo." (HEGEL, 1970, 8, p. 238).

Pode-se interpretar a discussão que Hegel empreende acerca da linguagem como uma radicalização das indicaçôes dadas acima por Kant, justamente porque a linguagem desempenhará um papel de destaque no itinerário que vai da intuição, a forma indeterminada e imediata de cognição, à forma consumada do conhecimento (HEGEL, 1970, 8, p. 254), que “[...] pertence somente ao pensar puro da razáo que conceitua (reinen Denken der begreifenden Vernunft)", a "intuição verdadeira e totalmente determinada" (HEGEL, 1970, 8, p. 254), num processo de "[...] engendramento das representaçôes universais", no qual o espírito teórico se mostra - ao contrário do "[...] engano desprovido de espírito [de se] aceitar que as representaçôes universais surgiriam sem atuação (Zutun) do espírito" -, como "ativo sobre si (selbsttätig)." (HEGEL, 1970, 8, p. 265).

Fixemos a conexão da linguagem com o problema da cognição. É como "imaginação produtiva" que a cognição empreende a "[...] unidade do universal e do particular, do interior e do exterior, da representação e da intuição." (HEGEL, 1970, 8, p. 266). Segundo Hegel, o signo (Zeichen) é o resultado mais bem acabado do "movimento dialético" (HEGEL, 1970, 8, p. 268) pelo qual se dá a "[...] ratificação objetiva, em si e para si, da representação universal.” (HEGEL, 1970, 8, p. 268). "O som que se articula ulteriormente para as representaçôes determinadas, a fala (Rede), e seu sistema, a linguagem (Sprache), fornece às sensaçôes, intuições, representaçóes, um segundo ser-aí, mais elevado do que o seu [ser-aí] imediato." (HEGEL, 1970, 8, p. 270). É a perenidade desse "segundo ser-ai" que explica por que, nesse momento, se passa da "[...] fantasia simbolizante e forjadora de signos (die symbolisierende und 
die zeichenmachende Phantasie) [...] para a memória (Gedächtnis)" (HEGEL, 1970, 8, p. 263), e desta para seu exercício puramente "mecânico." (HEGEL, 1970, 8, p. 279). "Este acolhimento tem, porém, o sentido (Sinn) de que a inteligência se faz através disso algo coisal (Sächlichen), de tal maneira que a subjetividade, em sua diferença em relação à coisa, torna-se algo inteiramente vazio." (HEGEL, 1970, 8, p. 279).

\section{Linguagem E A ConcepÇão Inferencial da Cognição}

Se, para Kant, Aristóteles foi, sob o ponto de vista da relação entre linguagem e pensamento categorial, o precursor (KANT, 1968, IV, p. 323), Hegel encontra no Estrangeiro de Eleia do Sofista de Platão o simbólico ponto de partida de seu holismó. "É a maneira mais radical de aniquilar todo discurso

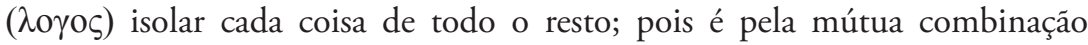
das formas ( $\tau \eta v \alpha \lambda \lambda \eta \lambda \omega v \tau \omega \nu \varepsilon 1 \delta \omega v \sigma v v \pi \lambda \circ \kappa \eta v)$ que o discurso ( $\lambda \mathrm{o} \gamma \mathrm{\sigma} \varsigma$ ) nasce." (PLATÃO, 1995, p. 259e). Para vencer as tendências relativistas do imobilismo (PLATÃO, 1995, p. 246b/c/e) e a "contradição performativa" da estabilização discursiva do múltiplo (PLATÃO, 1995, p. 238c/d) - que, criando a motivação para o "parricídio de Parmênides" (PLATÃO, 1995, p. 241e), ameaça, com uma inconsistente teoria da predicação, não somente os eleatas, mas também a ontologia dos defensores das formas imutáveis -, o Estrangeiro de Eleia propôe uma compreensão da dialética como ciência das relaçóes recíprocas e intrínsecas entre os gêneros supremos (PLATÃO, 1995, p. 253), a qual, além de explicar a possibilidade da relação dialética entre Uno e Múltiplo, na teoria da predicação ${ }^{5}$, possui traços holístico-semânticos

\footnotetext{
${ }^{4}$ Ao "enunciar" seu "método" dialético, Hegel o contrasta com uma modalidade puramente negativa de dialética, a qual "[...] aparece frequentemente também em Platâo (häufig auch bei Platon erscheint)." (HEGEL, 1970, 7, p. 83, grifo meu). Apesar disso, o entusiasmo diante do Sofista como momento antecipador de sua própria posição filosófica também é evidente (HEGEL, 1970, 18, p. 68).

${ }^{5}$ A discussão que precede a enunciação formal da ciência dialética foi direcionada pela necessidade de interpenetração e participação recíproca entre uno e múltiplo, enquanto condição de uma teoria consistente da predicação (PLATÁO, 1995, p. 251c). Em seguida, encaminha-se a compreensão da dialética como teoria da comunidade recíproca dos gêneros supremos (PLATÃO, 1995, p. 254c/d). Finalmente, depois de defendido o estatuto ontológico do não-ser como alteridade (PLATÁO, 1995, p. $258 \mathrm{~b} / \mathrm{c}$ ), o próprio princípio de nâo-contradição é enunciado, a partir do vislumbre dialético nas condiçôes ontológico-discursivas da comunidade dos gêneros, como condição da predicação (PLATÃO, 1995, p. 256 a/b). A dialética aparece, assim, como ciência das condições (contextuais e holísticas) da predicação e do $\lambda$ o
} 
(PLATÃO, 1995, p. 253e), contextualistas (PLATÃO, 1995, p. 261e, $267 \mathrm{a} / \mathrm{b})^{6}$ e linguístico-intersubjetivistas ${ }^{7}$.

É a uma compreensão de linguagem, herdeira dessas perspectivas e inimiga das tendências esotéricas e solipsistas ocasionadas pela indizibilidade, que o Hegel da Enciclopédia, apesar de tudo (HABERMAS, 2004, p. 217), ainda adere.

Enquanto a linguagem é a obra do pensamento (das Werk des Gedankens), também nela nada se pode dizer que náo seja universal. O que eu apenas viso (meine) é meu (mein), pertence-me enquanto a este indivíduo particular; mas, se a linguagem só expressa o universal, eu não posso dizer o que apenas viso. E o indizivel (das Unsagbare) - sentimento, sensação - não é o mais excelente, o mais verdadeiro; e sim o mais insignificante, o mais inverídico (das Unbedeutendste, Unwahrste). (HEGEL, 1970, 8, p. 70).

Tal compreensão da linguagem como das Werk des Gedankens é vital para se compreender tanto a assimilação que Hegel faz da crítica de Kant a Hume quanto sua própria crítica a Kant, a qual é, a propósito, localizada capciosamente, junto à apreciação de Hume (HEGEL, 1970, 8, p. 105).

A artimanha de Hegel é motivada pela sua tese fundamental acerca de Hume e Kant: ambos os paradigmas filosóficos tematizados na "segunda posição" padecem de uma mesma patologia, a saber: a subserviência à diferença intransponível entre forma e conteúdo (HEGEL, 1970, 8, p. 110), ao Unterschied der Elemente. Entretanto, enquanto a filosofia de Kant toma essa diferença reconhecidamente como ponto de partida, o empirismo é disso inconsciente, o que constitui sua ilusão-fundamental (Grundtäuschung), pois o empirismo busca uma "realização consequente" (HEGEL, 1970, 8, p. 107) como compreensão epistemológica da ciência natural moderna, ou

6 "É que, desde esse momento, ele nos dá alguma indicação relativa a coisas que são, ou se tornaram, ou foram, ou serão; não se limitando a nomear, mas permitindo-nos ver que algo aconteceu, entrelaçando verbos e nomes. Assim, dissemos que ele discorre, e nâo somente nomeia, e a este entrelaçamento

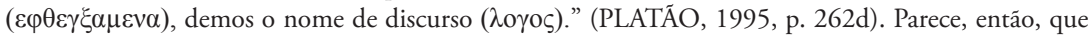
Platão antecipa a radicalizaçấo wittgensteiniana do assim chamado princípio fregeano do contexto. No Tractatus Logico-Philosophicus, Wittgenstein menciona que "[...] apenas a proposição tem sentido (Sinn); apenas no contexto de proposição um nome tem significado (Bedeutung).” (WITTGENSTEIN, 1984, 1, p. 20). Tal noção é radicalizada pragmaticamente no Livro Azul: "[...] compreender uma sentença significa compreender uma linguagem. Enquanto parte de um sistema de linguagem, pode-se dizer, uma sentença tem vida." (WITTGENSTEIN, 1984, 5, p. 21).

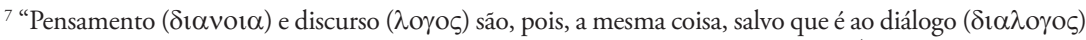
interior e silencioso da alma consigo mesma que chamamos pensamento." (PLATÃO, 1995, p. 263e). 
seja, como "wissenschaftlicher Empirismus" (HEGEL, 1970, 8, p. 107). Por um lado, o empirismo "[...] nega o suprassensível em geral, ou pelo menos seu conhecimento e sua determinidade, e só deixa ao pensar a abstração, e a universalidade e a identidade formais"; por outro lado, ao buscar embasar as pretensôes de validade da ciência moderna, tem de

[...] utilizar as categorias metafísicas de matéria, força, e também uno, múltiplo, universalidade, infinito etc... e, ainda mais, segue inferindo (fortschließst) pelo fio condutor de tais categorias, pressupondo e aplicando para isso a forma do inferir (Formen des Schließens) - / ainda mais que ele, em tudo isso, não compreende (weiß) que, desta maneira, ele próprio contém (enthält) e pratica metafísica, e emprega aquelas categorias e suas conexôes de uma maneira totalmente acrítica e inconsciente. (HEGEL, 1970, 8, p. 107-108).

A conclusão da crítica de Hegel a Hume é particularmente interessante para a formulação de sua concepção de uma metafísica inferencial, embasada na visualizaçáo dialética da suspensáo da diferença entre forma e conteúdo e na expectativa de responder de forma consistente às demandas epistêmicas da física moderna. Tal conclusão vem precedida por aquilo que poderia ser considerado um manifesto semântico-holista (BRANDOM, 2002, p. 182183) antecipado contra as tendências atomistas, empiristas e nominalistas da filosofia analítica da linguagem, em seus primórdios: "[...] um Erfahrungen zu machen, bedient sich der Empirismus vornehmlich der Form der Analyse." (HEGEL, 1970, 8, p. 110). "[E]nquanto esse sensível é - e permanece - um dado (ein Gegebenes) para o empirismo, temos uma doutrina da não-liberdade, porque a liberdade consiste justamente em que eu não tenha diante de mim nada absolutamente outro, mas dependa de um conteúdo que sou eu mesmo." (HEGEL, 1970, 8, p. 110). Afora a referência a certa operacionalização lógico-epistêmica do conceito kantiano-rousseauísta de liberdade como autodeterminação (MÜLLER, 1993), nesse texto fabuloso não somente fica clara a dívida de Hegel para com Kant na crítica ao empirismo, como também a ideia de uma metafísica inferencial é vinculada ao projeto de suspensão dos limites da explicação fornecida pelo empirismo para o modus operandi da ciência natural moderna, limites que são identificados pelo dado intransponível.

Eis aí, por conseguinte, uma caracterização mais cara à epistemologia contemporânea do caráter "inferencial" do pensamento infinito (unendliches Denken) ou da forma infinita (HEGEL, 1970, 6, p. 549), a qual Hegel pretende 
substituir às "[...] posiçóes do pensamento com respeito à objetividade." (HEGEL, 1970, 8, p. 95). Enquanto estas se aferram à "[...] representação da época moderna, segundo a qual o pensar seria sempre limitado", o pensar infinito, "[...] o pensar que está junto de si mesmo, consigo mesmo se relaciona [...] tem a si mesmo por objeto", um "[...] ein aufgehobener, ideeller Gegenstand" (HEGEL, 1970, 8, p. 95). Assim, Hegel propóe uma lógica como "ciência da ideia pura" (HEGEL, 1970, 8, p. 66) que, "[...] reunindo a atividade das formas do pensamento e sua crítica” (HEGEL, 1970, 8, p. 115), seja capaz de apresentar, de forma imanente, as mediações ou inferências necessárias, as quais são sempre intrínsecas à "experiência", trazendo à tona com isso a contribuição precisa dos conceitos puros e das inferências feitas a partir deles naquilo que é articulado intersubjetiva e linguisticamente como experiência humana. Trata-se, portanto, num só lance, da ruptura com a epistemologia moderna, considerando-se suas decorrências linguísticas - e, num certo sentido, ontológicas ${ }^{8}$; e, paradoxalmente, também da radicalização daquele projeto epistemológico, posto que inteiramente embasado no conceito de crítica e autorreferencialidade, na autonegatividade enquanto objeto da reflexão (PINKARD, 1996, p. 7), no operar sobre si o sich vollbringender Skeptizismus (HEGEL, 1970, 3, p. 71).

Interessa-me aqui, sobretudo, sublinhar essa situação histórica à qual pretende responder o projeto hegeliano (REDDING, 2007, p. 10/11). Náo é simplesmente uma alternativa à epistemologia moderna, mas, propriamente, sua konsequente Durchführung, sua "realização consequente" (HEGEL, 1970, 8, p. 107) como metafísica inferencial. Para Hegel, as ciências naturais modernas, essencialmente nomológicas e observacionais (HEGEL, 1970, 8, p. 77), pressupóem, para a satisfação de suas demandas epistêmicas, as implicaçôes da autorreferencialidade da experiência articulada linguisticamente, as decorrências da reflexáo constitutiva. A "[...] reflexão (Nachdenken) está sempre à busca do firme, do permanente, do determinado-dentro-de-si, e do que rege o particular. Esse universal náo se pode captar com os sentidos, e vale como o universal e o verdadeiro." (HEGEL, 1970, 8, p. 77). Nesse sentido, o déficit epistemológico das pretensões de validade objetiva ocasionado pela transformação, tipicamente moderna, da observação em ciência nomológica é compensado por uma metafísica inferencial, por meio da evidenciação do caráter mediacional ou inferencial daquilo que pode contar como experiência humana.

\footnotetext{
${ }^{8}$ Penso aqui, sobretudo, naquilo que, em geral, pode ser resumido numa célebre formulaçáo: “[...] ser que pode ser compreendido é linguagem.” (GADAMER, 1999a, p. 612).

${ }^{9}$ Brandom discute o papel da mediação (Vermittlung) na "[...] articulação inferencial de conteúdos induzida por relaçóes de negação determinada”, ou seja, relaçōes de incompatibilidade material
} 
Ao determinar desse modo o universal, encontramos que ele forma o contrário de um outro, e que esse outro é o simplesmente imediato, exterior, e singular em face do mediatizado, interior e universal. Esse universal não existe externamente enquanto tal [...] as leis do movimento dos corpos celestes não estão escritas no céu. $\mathrm{O}$ universal, pois, não se ouve nem se vê, mas é somente para o espírito. (HEGEL, 1970, 8, p. 77).

Para Hegel, caso se deva falar ainda, depois de Newton e Kant, de epistemologia, esta deve, como Logik, como "[...] espírito omnivivificante de todas as ciências" (der allbelebende Geist aller Wissenschaften) (HEGEL, 1970, 8, p. 77), explicitar o caráter espiritual da experiência humana como tal.

A explicitação da dimensão intersubjetiva da validade objetiva, necessária à concepção do déficit epistemológico das ciências nomológicas, pode ser visualizada na "gênese fenomenológica" das noçóes de conceito e espírito. Parece-nos plausível a tese, defendida entre os seguidores de Sellars, de que o desenvolvimento da "percepçáo" para o "entendimento" na Fenomenologia conteria uma ilustração do "contextualismo cognitivo" de Hegel (REDDING, 2007, p. 18) ${ }^{10}$. Além disso, recupero aqui o desenvolvimento da "consciência" para a "consciência de si", como demonstração da necessidade de um conceito inferencialmente articulado de conhecimento ${ }^{11}$, como movimento imanente desencadeado pelas insuficiências e instabilidade de uma forma nãoinferencial, pretensamente autossuficiente, de cognição (PINKARD, 1996,

(BRANDOM, 2002, p. 181). A incompatibilidade material se tornaria, para Hegel, a estrutura normativa mais fundamental dos conteúdos conceituais.

${ }^{10}$ Sobre isso, ver a discussão feita por Brandom sobre a articulação da noção de incompatibilidade material, enquanto o que permite a plena determinação de um conteúdo como plenamente individuado, diferenciando-o da simples negação de propriedades, no capítulo sobre a "Percepçáo" (BRANDOM, 2002, p. 179, 180, 184).

${ }^{11}$ Segundo Pinkard, sendo uma consideração reflexiva e autoconsciente dos padrōes e normas que reivindicam legitimidade, "[...] todas estas formas de autoconsciência tem uma estrutura mediada (isto é, inferencial).” (PINKARD, 1996, p. 8). Do ponto de vista histórico-filosófico, a tese de uma alegada "socialidade da razão", a qual pretende que esteja em curso, na Fenomenologia, "[...] uma teoria normativa do agir racional de indivíduos ocupando posiçóes no interior de um 'espaço social' compartilhado e governado por regras" (REDDING, 2007, p. 14), representa uma ainda mais estreita relação entre o idealismo alemão Kant, Fichte e Hegel e a "pragmática linguística." (WITTGENSTEIN, 1984, I, p. 344). A compreensão de frases está ligada ao engajamento apropriado nas práticas que tornam significativo determinado signo, nas práticas de seu uso, as quais são incorporadas em formas de vida socioculturais. Compreender uma linguagem, isto é, a diversidade do entrelaçamento entre os elementos linguísticos e as práticas extralinguísticas, é adquirir competências que habilitam à participação nessas atividades regradas. 
p. 46) ${ }^{12}$. Nesse sentido, a noção de reconhecimento corresponde à mediação entre a intersubjetividade dos sujeitos e a compreensão autoconsciente e compartilhada daquilo que pode pretender ser legítimo ou "revestido de autoridade" (authoritative reason), compondo assim o núcleo da concepção hegeliana de espírito (Geist) enquanto "forma autoconsciente de vida", enquanto "[...] forma de 'espaço social' refletindo sobre si mesmo acerca de se é satisfatório em seus próprios termos” (PINKARD, 1996, p. 8-9).

A "experiência" do entendimento na Fenomenologia de 1807 desemboca na relação entre os mundos sensível e inteligível. A tentativa de fornecer explicação do mundo objetivo, através de leis, faz do mundo inteligível, enquanto "cópia imediata e tranquila" (HEGEL, 1970, 3, p. 119) do mundo sensível, o reverso do mesmo: tornam-se "mundos invertidos" um para o outro. Para Hegel, é no recurso à explicaçâo fenomênica do jogo de forças que a infinitude "[...] surgiu, livre, pela primeira vez." (HEGEL, 1970, 3, p. 132). Para manter a "explicação científica" pelo dinamismo das forças, o entendimento enuncia a unidade dialética dos mundos sensível e inteligível e, portanto, o fenômeno como manifestação da essência. $\mathrm{O}$ entendimento experimenta, com a inversão do mundo decorrente da intenção estática da legalidade proveniente da ciência natural nomológica, a oposição absoluta entre fenômeno e essência, e contempla o surgimento de um objeto que é, na verdade, também ele mesmo: a vida ${ }^{13}$, "[...] essa inquietação absoluta do puro mover-se-a-si-mesmo [que faz com] que tudo o que é determinado de qualquer modo [...] seja antes o contrário dessa determinidade." (HEGEL, 1970, 3, p. 131). Eis por que é gerada, com a transformação do objeto em Si, uma relação que não é mais aquela entre consciência e objeto "sem consciência", mas a relação para si mesma, a essência da autoconsciência: o entendimento descobre, na estrutura do "ser-ooposto-de-si-mesmo", sua própria estrutura como consciência-de-si. "Quando a infinitude - como aquilo que ela é - finalmente é o objeto para a consciência,

\footnotetext{
${ }^{12}$ De acordo com Brandom, um dos principais objetivos de Hegel, nessa passagem, é " [...] desdobrar os compromissos implícitos nas concepçôes holistas de conteúdo e reunir as matérias-primas necessárias à explicação do mesmo." (BRANDOM, 2002, p. 187). Nesse sentido, "[...] náo se pode entender as relaçóes de incompatibilidade objetiva que articula a estrutura conceitual relacional em virtude da qual o mundo é determinado, a não ser que se entendam os processos e práticas constituindo o reconhecimento (acknowledgment) da incompatibilidade subjetiva dos compromissos que são, por meio disso, tratados como representaçóes de tal mundo.” (BRANDOM, 2002, p. 193).

${ }^{13}$ Trata-se, enquanto mediação do imediato consigo mesmo, da "infinitude simples - ou o conceito absoluto", o qual se deve "[...] chamar a essência simples da vida, a alma do mundo, o sangue universal, que onipresente não é perturbado nem interrompido por nenhuma diferença, mas que antes é todas as diferenças como também seu ser-suspenso; assim, pulsa em si sem mover-se, treme em si sem inquietar-se." (HEGEL, 1970, 3, p. 131).
} 
então a consciência é autoconsciência." (HEGEL, 1970, 3, p. 132). "Entender o mundo objetivo como determinado contém, para Hegel, a tese de que ele tem de ser entendido como uma estrutura holistica relacional." (BRANDOM, 2002, p. 208). O entendimento se torna objeto de si mesmo e, nessa medida, não simplesmente objeto, mas também sujeito: “[...] essa unidade é também [...] seu repelir-se de si mesma; e esse conceito se fraciona na oposição entre a autoconsciência e a vida." (HEGEL, 1970, 3, p. 138). A autoconsciência é a infinitude como $\mathrm{tal}^{14}$, a totalidade articulada e autodiferenciadora dos conteúdos, embora seja também, primeiramente, essa universalidade simples, para si imediata e pretensamente oposta à universalidade da vida: desejo.

A infinitude do entendimento como objeto de si mesmo significa que o entendimento é uma "[...] estrutura que estabelece suas próprias condiçóes" (PINKARD, 1996, p. 43), ou seja, as especificaçôes que o entendimento pensara ter identificado nas coisas elas mesmas são "[...] parte da estrutura de nosso sistema inferencial.” (PINKARD, 1996, p. 43). A presente inflexão na Fenomenologia nada mais é do que a radicalização da "revolução copernicana", na medida em que a suspensão do entendimento na autoconsciência, além de solapar o absolutismo reclamado pelo representacionalismo, significa que doravante o objeto da reflexão filosófica não são mais "coisas em si mesmas", essências ou indivíduos com as quais temos acquaintance, mas a posição que assumimos, quando conhecemos as coisas em si, dessa maneira específica, no "espaço de razóes", ou seja, no emprego de e compromisso com "[...] regras e normas semânticas de pensamento inferencial.” (HABERMAS, 2004, p. 136).

A solução hegeliana para a cisão representacionalista entre forma $\mathrm{e}$ conteúdo é a visualização dialética de sua originária coabitação ${ }^{15}$. Como sempre, em Hegel, tal visualização conduz, por uma "fundamentação regressiva”, a uma reinterpretação, à luz da coabitação originária, de ambos os polos isolados (HEGEL, 1970, 8, p. 187). Com efeito, o projeto hegeliano conecta a natureza inferencial da experiência humana, a estruturação e a sedimentação linguística dessa experiência, bem como a necessidade de

\footnotetext{
${ }^{14}$ Para uma visualização da relação entre esse conceito de infinitude e o "holismo semântico", um "[...] todo tendo dentro dele as diferenças, como uma estrutura articuladora essencial", ver: Brandom (2002, p. 185-186).

${ }^{15}$ A dialética especulativa espera, desse ponto de vista epistemológico, "[...] entender as estruturas holísticas atravessando os momentos, começando com concepções das coisas como são imediatamente ou em si mesmas, movendo-se em seguida à captaçáo das mesmas como o que são mediadas ou para outros, e então para entender o que elas são em si mesmas como constituídas pelo que são para outros, enquanto imediatidade mediada." (BRANDOM, 2002, p. 209).
} 
reinterpretar, à luz desses elementos, os polos isolados e tradicionalmente compreendidos como "forma lógica pura" e "conteúdo não-conceitual", em direção ao conceito hegeliano de "conceito", "[...] o grande sistema holístico, inferencialmente articulado, de conceitos determinados e de juízos articulados por aqueles conceitos." (BRANDOM, 2002, p. 224).

Em outro contexto, Hegel faz ainda outras consideraçóes interessantes para que se compreenda a estruturação linguística da dimensão objetiva da validade e, por conseguinte, para uma versão inferencial da cognição. Trata-se da articulação linguística da cognição, tencionada em 1804. A compreensão hegeliana da consciência como medium se dirige contra a concepção mentalista de uma subjetividade exteriormente limitada e autossuficiente, a qual é, por isso, presa de dualismos entre o interior e o exterior, ou entre o público e o privado $^{16}$. Trata-se da pré-estruturação das relaçóes sujeito-objeto, antecipadoras da própria efetividade enquanto experiência consciente e na qual a relação entre sujeito existe e pode ser modificada.

No que concerne à linguagem como medium, a consciência singular é previamente articulada em conexão com todos os objetos “exteriores", o que leva justamente à suspensão da contraposição entre o sujeito que representa e o objeto representado. Para Hegel, nesse conceito de espírito,

[...] seus momentos contrapostos são da mesma forma conceitos, universais em geral e, por isso, não se relacionam um ao outro enquanto absolutamente contrapostos, mas antes se relacionam formalmente um ao outro no elemento simples da consciência, [não como] intactos em seu serpara-si, e sim se suspendendo um em face do outro em sua forma, e fora da mesma permanecendo ainda para si. (HEGEL, 1986, p. 195).

Em outras palavras, a consciência cognoscente é como que forjada na antecipação "linguística" da suspensão de conceito e objeto, de maneira que a capacidade cognitiva do sujeito singular se exerce, na medida em que o arcabouço das experiências possíveis é previamente articulado linguisticamente, quer como intuição, quer como conceito, sempre apoiada no estofo linguístico anterior à própria contraposição.

\footnotetext{
16 "Hegel refuta a tese de que o sujeito cognoscente, falante e agente se encontra diante da tarefa de construir uma ponte sobre o abismo entre si e o outro separado dele. Um sujeito que está de antemão junto de seu outro não percebe nenhum déficit que exija compensação. Percepções e juízos se articulam em uma teia de conceitos previamente fechada linguisticamente [...] Tal sujeito náo pode estar junto a si mesmo sem estar junto ao outro." (HABERMAS, 2004, p. 195).
} 
A existência do medium linguístico é o protótipo do mundo conhecido, a idealidade da natureza: a "forma" da cognição é imediatamente, pela linguagem, a exterioridade de que fala. A linguagem é, portanto, a um só tempo, o meio e o produto da contraposição interior/exterior. "A consciência existe primeiro como memória e seu produto, a linguagem." (HEGEL, 1986, p. 195). Enquanto nexo unitário do medium linguístico, a memória forma, por sua vez, o arcabouço linguístico em que toda a experiência cognitiva está pré-estruturada: trata-se igualmente, com efeito, da cognição em sua existência perene e, por isso, excede, como tal, a singularidade de um sujeito cognoscente. "Somente em um povo existe aquilo - já posto como suspenso, existente como consciência universal, ideal - que a memória, o tornar-se linguagem (das Werden zur Sprache), torna primeiramente ideal.” (HEGEL, 1986, p. 226). Com a memória, a atividade cognitiva do sujeito singular aponta já para a sua plena efetivação e para sua existência contínua no horizonte histórico da existência de um povo, de uma comunidade de indivíduos que compartilham uma língua e uma tradição, para sua existência como ser-reconhecido: $o$ reconhecimento tem, para Hegel, uma estruturação linguística (HEGEL, 1986, p. 226-227), a qual pré-estrutura pretensôes de validade semântico-objetivas ${ }^{17}$ : "Essa substância universal fala sua linguagem universal nos costumes e nas leis de seu povo.” (HEGEL, 1970, 3, p. 265).

\section{Forma Gramatical e Conteúdo Lexical: a linguagem entre o "Lógico" E A “HISTORICIDADE"}

Como se estivesse recomendando o ensino de gramática às crianças, para que pudessem adquirir consciência do caráter inferencial e reflexivo do conhecimento (ver HEGEL, 1970, 8, p. 76 e 84), Hegel concebe o projeto "epistemológico" mediacional e inferencial de eliminação do intransponível Gegebenes, o qual caracteriza as teorias do conhecimento criticadas na zweite Stellung do Vorbegriff da Enciclopédia de 1830, de maneira a vincular essa “[...] explicitação do caráter espiritual da experiência”, essas necessárias inferências categoriais do conteúdo, estreitamente ao problema de sua estruturação linguística.

\footnotetext{
${ }^{17}$ Enquanto "[...] reconstruída [...] em um povo", a linguagem se torna um aniquilar do exterior que é ele mesmo uma exterioridade, "[...] o qual tem de ser aniquilado, suspenso, a fim de se tornar linguagem designativa (um zur bedeutenden Sprache zu werden), tornar-se aquilo o que ela é em si, segundo seu conceito. Portanto, ela é no povo como um outro algo morto que náo ela mesma, tornando-se totalidade ao ser superada enquanto um exterior e ao chegar a seu conceito (zu ihrem Begriff wird)." (HEGEL, 1986, p. 227).
} 
Acredita-se habitualmente que o absoluto deve estar situado muito além; mas ele é justamente o que está de todo presente (das ganz Gegenwärtige), mesmo sem consciência expressa disso, sempre levamos conosco e utilizamos. Tais determinaçóes-de-pensamento (Denkbestimmungen) estáo sempre depositadas (niedergelegt), sobretudo, na linguagem [...] as noçóes lógicas (Die logischen Gedanken), entretanto, não são nenhum somente em relação a qualquer outro conteúdo; mas qualquer outro conteúdo é apenas um somente em relação às noçôes lógicas. (HEGEL, 1970, 8, p. 84).

Mas qual é a relação, pretendida por Hegel, entre a linguagem, em seus múltiplos aspectos, e a significação dos nomes? Signo é uma intuição (Anschaunng) ou imagem (Bild) que "[...] recebeu em si mesma [...] uma representação independente (selbständige), a sua significação (Bedeutung).” (HEGEL, 1970, 8, p. 269). Como "[...] fantasia forjadora de signos (Zeichen machende Phantasie)" (HEGEL, 1970, 8, p. 265-266), a inteligência ou cognição acaba por "[...] fazer de si mesma ser (Sein), tornar-se coisa (Sache)". "Ativa nessa determinação, ela é [enquanto] se exteriorizando (sich äußernd), produzindo intuição." (HEGEL, 1970, 8, p. 265-266). O sistema linguístico formado no processo de cognição, entendido aqui pelo escopo geral de um processo de exteriorização/extrusão do espírito teórico (HEGEL, 1970, 8, p. 277), é vislumbrado por Hegel em seu caráter ambíguo. Por um lado, a “[...] arbitrariedade [...] da ligação da matéria sensível com a representação universal tem por consequência necessária que se tem de aprender primeiramente a significação (Bedeutung) do signo. Isso é válido principalmente para os signos da linguagem (Sprachzeichen)." (HEGEL, 1970, 8, p. 268). Por outro lado, "[...] o [elemento] formal da linguagem é, contudo, a obra do entendimento, o qual insere nela suas categorias. Este instinto lógico produz o [elemento] gramatical.” (HEGEL, 1970, 8, p. 271). Portanto, a linguagem é um sistema de conexões "arbitrárias", no sentido de "convencionais", passíveis de aprendizado somente nas práticas articuladas linguisticamente. Todavia, é também a capacidade de expressão, graças ao seu elemento formal como obra do entendimento, que permite o desdobramento do "[...] pensar puro da razão que conceitua." (HEGEL, 1970, 8, p. 254). Hegel se coloca, do ponto de vista da história da filosofia da linguagem, na interessante posição que tenta preservar, num só golpe, a tese contextualista do inessencialismo da linguagem, a tese hermenêutica da historicidade do meio linguístico, sem sucumbir à ameaça de incomensurabilidade entre linguagem e a pretensão de universalidade do pensamento especulativo. "A teoria hegeliana da 
linguagem [...] explicitamente determina a forma universal estruturante que permanece apenas implícita no uso da linguagem cotidiana e, reciprocamente, revela a significativa inter-relação do léxico como pressuposto pela forma da gramática." (VERNON, 2007, p. 117).

Num primeiro momento, Hegel parece simplesmente estar reforçando certas tendências mentalistas, típicas da consideração da linguagem que, muitas vezes, se coaduna com a moderna teoria do conhecimento, a qual opta, paradigmaticamente com Locke, por uma ideia de linguagem como mera verbalização dos pensamentos. Porém, para Hegel, através da "negatividade do signo linguístico", "[...] aquilo é alterado [passando] de um exterior para um interior, sendo conservado nesta forma reconfigurada (umgestalteten).” (HEGEL, 1970, 8, p. 279) Não se trata, por conseguinte, de transformar o interior em palavras, mas de reconfigurar espiritualmente o exterior, conferindo-lhe a interioridade espiritual de uma forma de vida, tornando-o Gestalten einer Welt (HEGEL, 1970, 3, p. 325). As palavras não são a exteriorização do interior, no sentido em que fornecem as coisas do mundo suas etiquetas: "[...] as palavras se tornam um ser-aí vivificado pelo pensamento.” (HEGEL, 1970, 8, p. 279).

Apesar do jargão um tanto híbrido que conserva, ainda que os submeta a um novo significado, termos caros ao pensamento moderno, Hegel demonstra o caráter pós-kantiano de sua consideração da linguagem pela vinculação da mesma não a uma doutrina da verbalização de vivências cujo acesso é privado, mas justamente pelo seu escopo propriamente "espiritual" ou, mais especificamente, pela relação intrínseca entre a linguagem e o problema da dimensão intersubjetiva da validade. Primeiramente, não há, para Hegel, de um lado, o pensamento e, de outro, a linguagem como pura exteriorização pensamento. "É em nomes que nós pensamos." (HEGEL, 1970, 8, p. 277). Eis por que o ser-aí espiritual do pensamento como linguagem seja "[...] absolutamente necessário aos nossos pensamentos.” (HEGEL, 1970, 8, p. 279). A interioridade que vem à tona como linguagem não é uma interioridade solipsista, vivencial, individual, mas a interioridade intersubjetiva do espírito.

Nós somente sabemos de nossos pensamentos, somente temos pensamentos determinados e efetivos, quando nós lhes fornecemos a forma da objetividade (Gegenständlichkeit), do ser-diferenciado (Unterschiedenseins) em relação à nossa interioridade (Innerlichkeit), [quando] portanto, fornecemos-lhes a configuraçáo (Gestalt) da exterioridade (Äußerlichkeit) e, na verdade, de uma tal exterioridade que porta, ao mesmo tempo, a marca característica da mais elevada interioridade (Innerlichkeit). (HEGEL, 1970, 8, p. 279). 
Eis aí o registro que me interessa frisar: a linguagem é o âmbito em que não somente vem à tona a dimensão intersubjetiva da validade, mas também o ambiente em que essa dimensão é aferível, tornando-se consciente de si mesma como tal, como validade, ambiente no qual essa dimensão intersubjetiva da validade é não somente aferível como tal, mas eventualmente também modificável. "O nome (Name) é, assim, a coisa (Sache), tal como ela está presente no reino da representação (Reiche der Vorstellung) e [nele] tem validade (Gültigkeit).” (HEGEL, 1970, 8, p. 277).

"Forma e conteúdo linguísticos [...] se pressupóem reciprocamente e se fundam um ao outro. Nós podemos, entâo, definir a linguagem como a identidade-na-diferença da forma gramatical universal e do conteúdo lexical particular." (VERNON, 2007, p. 116). Chegamos assim a uma tese de grande envergadura: a mútua implicação entre pensamento especulativo e linguagem, ou seja, a ideia da própria linguagem como meio de expressão de tudo o que, no jargão hegeliano, mereça o nome de pensamento, em sentido amplo ou restrito. E, para Hegel, não há aqui nada que deva ser lamentado, pois

[... é é ridículo considerar o estar-vinculado do pensamento à palavra como uma falha do primeiro ou como uma lástima [...] A palavra fornece aos pensamentos, por conseguinte, seu ser-aí mais digno e verdadeiro [...] Assim como o verdadeiro pensamento é a coisa, da mesma forma também [verdadeira é] a palavra, quando ela é utilizada (gebraucht) pelo pensamento verdadeiro. Por isso, quando a inteligência se preenche com a palavra, acolhe dentro de si a natureza da coisa (Sache). (HEGEL, 1970, 8, p. 279).

\section{Dialética e a Compreensão Hermenêutica de Linguagem: a apropriaçấo CRítica de Hegel por Gadamer}

Em sua crítica à posição ingênua da metafísica anterior a Hume ${ }^{18}$, Hegel sugere igualmente que ela padece da insuficiência de considerar os predicados numa relação fundamental de exterioridade uns para com os outros e com o próprio "sujeito". Sem deixar "[...] o objeto determinar-se livremente a partir de si mesmo, pressupondo-o já pronto" (HEGEL, 1970, 8, p. 97), esse essencialismo estático não alcança a consciência nem mesmo de que

\footnotetext{
${ }^{18}$ A "ingenuidade" da metafísica pré-crítica consiste em tomar como objetos "[...] totalidades que pertencem em si e para si à razão" (HEGEL, 1970, 8, p. 96), contudo, tratando-os como "apoio fixo" (HEGEL, 1970, p. 96), como "[...] sujeitos dados como já prontos" (HEGEL, 1970, p. 96), resta adotar a doutrina tradicional da predicação para expor o conteúdo desses objetos.
} 
[...] a forma da proposição (die Form des Satzes), ou mais precisamente a do juízo (Urteil), é imprópria para exprimir (ausdrücken) o concreto - e o verdadeiro é concreto - e o especulativo: o juízo (Urteil) é, por sua forma, unilateral; e, nessa medida, é falso. (HEGEL, 1970, 8, 97).

Hegel tangencia aqui a ideia, indicada na Fenomenologia, da contraposição entre a noçáo apofântica da proposição e sua estrutura propriamente especulativa, o "[...] conflito da forma de uma proposiçáo em geral e da unidade do conceito que a destrói." (HEGEL, 1970, 3, 58). Tal doutrina é uma crítica à unilateralidade do $\lambda \circ \gamma \circ \varsigma \alpha \pi 0 \varphi \alpha v \tau \iota \kappa o \varsigma$ e, nesse sentido, o acesso a uma forma menos unilateral de racionalidade: "[...] apenas aquela exposição filosófica lograria ser plástica [, a saber]: a que excluísse estritamente a forma da relação costumeira das partes da proposiçâo.” (HEGEL, 1970, 3, p. 59). Em sua relação com a doutrina da predicação proveniente da lógica tradicional, tal doutrina pode ser interpretada como um ataque à pressuposiçáo ingênua de um essencialismo estático, conduzindo à ideia de que a verdadeira natureza do sujeito não pode ser pressuposta como apoio fixo, ao qual são acrescentadas determinaçôes extrínsecas, no entanto, mostra-se apenas no movimento pelo qual o sujeito se torna o próprio conteúdo da determinaçãa ${ }^{19}$. Esse essencialismo dinâmico (HOULGATE, 1986, p. 148-156) - intimamente vinculado à célebre fórmula segundo a qual "[...] o verdadeiro é o delírio báquico (bacchantischer Taumel), onde não há membro que não esteja ébrio" (HEGEL, 1970, 3, p. 45) - que abrange tanto a diferença quanto a identidade entre sujeito e predicado ${ }^{20}$, tem severas consequências para uma consideração da linguagem.

"É verdade que [...] a dialética de Hegel se guia de fato pelo espírito especulativo da linguagem.” (GADAMER, 1999a, 679). Ao destituir a doutrina tradicional da predicação de sua prerrogativa na exposição do conteúdo, a filosofia especulativa incumbe a linguagem como tal - não apenas seu refinamento lógico-formal, mas o próprio desdobramento linguístico do pensamento especulativo - da tarefa de constituir o meio em que a "[...] identidade das determinaçóes diferentes” (HEGEL, 1970, 3, 45), o especulativo como tal, pode vir à tona.

\footnotetext{
19 " $[\mathrm{U}] \mathrm{ma}$ vez que o predicado é ele mesmo exprimido como um sujeito, enquanto $o$ ser, enquanto a essência, a qual esgota a natureza do sujeito, o pensar encontra o sujeito imediatamente no predicado." (HEGEL, 1970, 8, p. 96).

20 “[...] na proposiçấo filosófica, a identidade do sujeito e do predicado nấo pode aniquilar a diferença dos mesmos, a qual exprime a forma da proposiçấo. Antes, a identidade deles deve surgir como uma harmonia." (HEGEL, 1970, 3, p. 58).
} 
Enquanto cada lado desta identidade pode e, de fato, tem de ser determinado em abstração do outro, é apenas pela captação de seu retorno à unidade que nós realmente entendemos a natureza da linguagem. Esta unidade é articulada na análise hegeliana da "sentença especulativa". (VERNON, 2007, p. 117).

Trata-se aqui da mútua implicação entre pensamento especulativo e linguagem ${ }^{21}$, ou seja, a ideia da própria linguagem como meio de expressão de tudo o que, no jargão hegeliano, mereça o nome de pensamento, em sentido amplo ou restrito ${ }^{22}$.

A "dialética da certeza sensível” (HEGEL, 1970, 3, p. 87) é um momento paradigmático para se compreender a relação entre experiência consciente e a linguagem. ${ }^{23} \mathrm{Em}$ sua forma mais radical, a certeza sensível ergue a pretensão "[...] eu sou puro intuir" (HEGEL, 1970, 3, p. 87). É claro que, no itinerário de figuras da consciência, o resultado imediato dessa experiência ${ }^{24}$ é a percepção da coisa pela mediação da propriedade (Eigenschaft) (HEGEL, 1970, 3, p. 93). Todavia, na "experiência da certeza sensível" (HEGEL, 1970, 3, p. 87) se insinua, sobretudo para o "nós fenomenológico", "[...] o falar, que tem uma natureza divina" (HEGEL, 1970, 3, p. 91). Assim, a experiência da pretensão do puro intuir é a mediação linguística, em sua acepção mais geral.

\footnotetext{
${ }^{21}$ Essa aproximação suscita a difícil questão de como a linguagem pode abrigar a estrutura pura da "forma infinita" e a própria historicidade. "Forma e conteúdo linguísticos [...] se pressupóem reciprocamente e se fundam um ao outro. Nós podemos, então, definir a linguagem como a identidade-na-diferença da forma gramatical universal e do conteúdo lexical particular." (VERNON, 2007, p. 116).

${ }^{22} \mathrm{E}$, para Hegel, não há aqui nada que deva ser lamentado, pois "[...] é ridículo considerar o estarvinculado do pensamento à palavra como uma falha do primeiro ou como uma lástima [...] A palavra fornece aos pensamentos, por conseguinte, seu ser-aí mais digno e verdadeiro [...] Assim como o verdadeiro pensamento é a coisa, da mesma forma também [verdadeira é] a palavra, quando ela é utilizada (gebraucht) pelo pensamento verdadeiro. Por isso, quando a inteligência se preenche com a palavra, acolhe dentro de si a natureza da coisa (Sache).” (HEGEL, 1970, 8, p. 279).

23 "Linguagem" entendida no bojo de uma teoria geral da "mediaçâa" (Vermittlung), enquanto "passagem" (Übergang) de "[...] palavras que só exprimem (ausdrücken) a intuição como algo imediato, mesmo que seja somente passagem para outra proposição.” (HEGEL, 1970, 3, p. 22).

${ }^{24}$ A certeza sensível é a "história de sua experiência" (HEGEL, 1970, 3, p. 89), a saber: aqueles que defendem qualquer forma autossuficiente de conhecimento imediato, sobre "[...] coisas efetivas, absolutamente singulares, totalmente pessoais e individuais [...] não dizem aquilo que visam. Se eles efetivamente quisessem dizer este pedaço de papel, o qual visam - e eles quereriam dizê-lo - então isso é impossível, pois o isto sensível, que é visado, é inalcançável à linguagem, a qual pertence à consciência, àquilo [que é] em si universal [...] eles dizem delas somente o universal. Por conseguinte, aquilo que é denominado inexprimível (das Unaussprechliche) nada mais é do que o não-verdadeiro, nâo-racional, simplesmente visado." (HEGEL, 1970, 3, p. 90-91).
} 
É novamente a compreensão da linguagem como das Werk des Gedankens $^{25}$, permanente tensão entre universal e singular, que é vital para se compreender a reabilitação hermenêutica feita por Gadamer, a partir de ressalvas nietzschianas e heideggerianas ${ }^{26}$ da noção hegeliana de "sentença especulativa" 27 . Se todo processo de compreensão consiste num acontecimento de linguagem semelhante "[...] àquele diálogo interno da alma consigo mesma”28, também fenômenos "privativos" são acontecimentos de linguagem

25 "Na medida em que a linguagem é a obra do pensamento (das Werk des Gedankens), também nela nada se pode dizer que não seja universal. O que eu apenas viso (meine) é meu (mein), pertence-me enquanto a este indivíduo particular; mas, se a linguagem só expressa o universal, eu não posso dizer o que apenas viso." (HEGEL, 1970, 8, p. 70).

${ }^{26}$ Não posso aqui detalhar essa questão. Refiro-me, pelo lado nietzschiano dessas ressalvas, à preservação do inacabamento do sentido poético, da imagem, da intuição; pelo lado heideggeriano das ressalvas, refiro-me à percepção da tensão entre identidade e diferença à luz de uma radicalização ontológica da noção hermenêutica de imagem linguística do mundo (HABERMAS, 1999, capítulo 1).

${ }^{27}$ Aludo, neste ponto, a uma bela análise da relação entre Hegel e a hermenêutica filosófica, através de uma filosofia da linguagem pensada por meio da "sentença especulativa" (VERNON, 2007, p. $118 \mathrm{ss}$ ), e também a uma percepção da importância da "sentença especulativa" para a filosofia da linguagem em Hegel (HOULGATE, 1986, p. 115 ss.) Tal estrutura especulativa do meio linguístico, uma estrutura ontológica universal que preside a constituição fundamental de tudo aquilo a que a compreensão pode se voltar, conduz à ideia de que "[...] ser que pode ser compreendido é linguagem" (GADAMER, 1999a, p. 612). Há que se considerar aqui a amplitude, significado e importância do hermeneutic turn, bem como da virada linguística na própria hermenêutica (ROHDEN, 2005, p. 64-75) (LAFONT, 1999, p. 55 ss). Essa "virada hermenêutica da ontologia", embasada no modo especulativo da linguagem, em seu significado ontológico universal (GADAMER, 1999a, p. 613), e na tese de que a constituição especulativa do ser que subjaz à hermenêutica tem a mesma amplitude universal que a razão e a linguagem (GADAMER, 1999a, p. 615), faz da linguagem não só " medium da experiência hermenêutica” (GADAMER, 1999a, p. 497), mas também - e por isso mesmo - a própria estruturação da experiência do mundo (GADAMER, 1999a, p. 589). A “sentença especulativa" não é o único tópico do pensamento hegeliano que influencia a hermenêutica filosófica, a qual absorve também o conceito hegeliano de experiência (ROHDEN, 2005, p. 83-93).

${ }^{28}$ Hegel e Gadamer mantêm uma relação íntima com o Sofista de Platão, sobretudo com: (1) suas

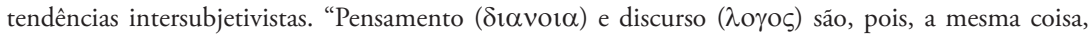
salvo que é ao diálogo ( $\delta \mathrm{i} \alpha \lambda \mathrm{o} \gamma \mathrm{o})$ ) interior e silencioso da alma consigo mesma que chamamos pensamento." (PLATÃO, 1995, p. 263e) (GADAMER, 1999b, p. 180); (2) o caráter refratário às tendências esotéricas ocasionadas pela indizibilidade. No Sofista, o Estrangeiro tende a considerar o caráter místico e esotérico do discurso sobre o ser como produzindo indizibilidade (incomunicabilidade) e ensejo a experiências iniciáticas (PLATÃO, 1995, p. 243b-c). Também Hegel pretende que sua dialética especulativa disponha racionalmente o místico e o esotérico, rebaixando-o ao simples ponto de vista do entendimento (HEGEL, 1970, 7, p. 307) (HEGEL, 1970, 8, p. 226 e 279). Nesse sentido, a dialética do ser e do nada, que resulta no devir e no ser determinado, seria uma resolução da dialética da indizibilidade. O nada como indizível (das Unsagbare, die bloße Meinung) (HEGEL, 1970 , 8, p. 187) ameaçaria o discurso sobre o que é: a mediaçăo, o nexo inferencial, presidiria, como autonegaçấo do indeterminado, a possibilidade da predicaçấo; e (3) o contextualismo. (PLATÃO, 1995 , p. 261e e 267a/b) "É que, desde esse momento, ele nos dá alguma indicação relativa a coisas [...] não se limitando a nomear, mas permitindo-nos ver que algo aconteceu, entrelaçando verbos e nomes. 
(GADAMER 1999b, p. 217). É constitutiva da vida da linguagem a tensão entre o convencionalismo e a individualização (GADAMER 1999b, p. 208), entre o universal e o singular, uma tensão que eclode em toda a sua liberdade no uso poético (GADAMER 1999b, p. 208). Antecipando textos mais recentes (LAWN, 2004, p. 125-131), Gadamer sustenta aqui o uso poético da linguagem como caso paradigmático ao qual a hermenêutica deve, em sua crítica à objetivação semântica da linguagem, voltar-se, às "[...] formas em que o dizer movimenta-se para trás de si mesmo": "[...] o dizer implica sempre um sentido implícito que só exerce sua função de sentido permanecendo como pano de fundo." (GADAMER, 1999b, p. 210).

Para além de sua significação puramente instrumental, reificada, objetificada, favorecida no ocidente (GADAMER, 1999b, p. 174-176), a linguagem tem, para a hermenêutica, especificidades constitutivas. Primeiramente, o "[...] esquecimento essencial de si mesmo que advém à linguagem", em virtude do que o "[...] fenômeno da linguagem é tão enigmático, atrativo e fugidio" (GADAMER, 1999b, 233), de maneira que sua concretização efetiva "[...] faz com ela desapareça detrás daquilo que nela se diz.” (GADAMER, 1999b, p.178-179). Em segundo lugar - e de maneira fortemente vinculada ao caráter tanto mais inconsciente quanto mais vivo do ato de linguagem -, está a dimensão primordialmente espiritual, supraindividual da linguagem falada, sua realidade dinâmica, dialógica e lúdica, a qual provoca, frente à aparência de disponibilidade e controle por parte da consciência individual, a "[...] saída extática de si próprio para um nexo dinâmico que desenvolve sua própria dinâmica" (GADAMER, 1999b, p. 180). Sob seu terceiro aspecto específico e que excede o significado puramente instrumental, a linguagem póe em xeque, com sua oniabrangência, a inefabilidade. "A negação da linguagem testemunha sua capacidade de buscar expressão para tudo.” (GADAMER, 1999b, p. 217). Por mais inacabado que seja o diálogo, a linguagem sempre denuncia, em seu "mover-se para trás de si mesma”, paradigmaticamente na poética, a tensão entre o dito e o não-dito como forjadora do sentido poético linguisticamente inacabado ${ }^{29}$.

Assim, dissemos que ele discorre, e não somente nomeia, e a este entrelaçamento ( $\varepsilon \phi \theta \varepsilon \gamma \xi \xi \alpha \mu \varepsilon v \alpha)$,

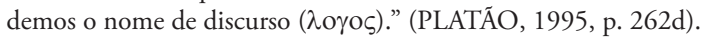

${ }^{29}$ Para uma boa sinopse: “[...] em todos os nossos pensamentos e conhecimentos sempre já fomos precedidos pela interpretaçáo do mundo feita na linguagem [...] a linguagem representa o verdadeiro vestígio de nossa finitude. A linguagem sempre já nos ultrapassou. O parâmetro para medir seu ser não é a consciência do indivíduo. Não existe consciência individual que pudesse conter sua linguagem. Mas como existe então a linguagem? Com certeza não sem a consciência individual. Mas também não na mera reunião de muitas consciências individuais." (GADAMER, 1999b, p. 178). 
Uma maneira de perceber como a hermenêutica de Gadamer procura fazer frente à reificação e à instrumentalização da linguagem é considerar sua diferenciação entre enunciado e enunciação (GADAMER, 1999b, p. 226), entre enunciado proposicional e a "dialética da palavra", sua envergadura entre uno e múltiplo (GADAMER, 1999a, p. 664). Por meio desta, Gadamer pretende fazer retroceder a opçáo decisiva do ocidente pelo logos apofantikos, a linguagem tomada na pura imanência do dizer, do "[...] mostrar-se do que foi dito" (GADAMER, 1999b, p. 227). Como resultado, tem-se que a visão holística ou hermenêutica da linguagem não se reduz a um contextualismo da palavra (GADAMER, 1999b, p. 332), não se reduz a conceber “[...] o fenômeno da linguagem a partir do enunciado isolado, mas a partir da totalidade de nosso comportamento no mundo, o qual é por sua vez também uma vida em diálogo.” (GADAMER, 1999b, p. 224). Para Gadamer, a autoproteção da linguagem frente à força corrosiva da reflexão, o autoesquecimento que impele o falar para além do enunciado isolado em direção ao inconsciente, "a unidade vital da linguagem", "[...] aparece claramente, sobretudo, no uso poético da linguagem.” (GADAMER, 1999b, p. 223)

Nos últimos capítulos de Verdade e Método, Gadamer retoma inspirações fundamentais da dialética especulativa de Hegel, a fim de tornar mais explícito o caráter antissubjetivista da experiência hermenêutica estruturada linguisticamente ${ }^{30}$. "Esta dialética não é, pois, um fazer externo de um pensar subjetivo, mas a alma própria do conteúdo [...] o pensar enquanto subjetivo apenas olha, sem adicionar ingrediente algum de sua parte [...] a ciência tem somente a tarefa de trazer à consciência esse trabalho próprio da razão da coisa." (HEGEL, 1970, 7, p. 84). Certamente, Gadamer tende a concordar de um modo geral com Hegel na ideia implícita, vista acima, de que "[...] a verdade da tradição é como o presente que está imediatamente aberto aos sentidos, [mas] o modo de ser da tradição não é imediatamente sensível. Ele é linguagem." (GADAMER 1999a, p. 671). Contudo, garante Gadamer, se a experiência hermenêutica tem, por um lado, sua própria dialética enquanto “[...] um fazer da própria coisa”, na medida em que “[...] o desenvolvimento do todo do sentido a que está orientada a compreensão nos força à necessidade de interpretar e de novo nos retirar" (GADAMER 1999a, p. 671), por outro lado, Gadamer vê a insuficiência da dialética clássica na submissão da linguagem a

\footnotetext{
${ }^{30} \mathrm{~A}$ hermenêutica se dirige à refutação de qualquer teoria que negue a unidade interna entre palavra e coisa, ou seja, a recíproca constituiçáo entre mundo e linguagem, a linguisticidade originária do mundo, que é a contrapartida da mundanidade originária da compreensão linguística (GADAMER 1999a, p. 522).
} 
seu enunciado (GADAMER 1999a, p. 679), no afă de “[...] liberar-se por completo do poder da linguagem" (GADAMER 1999a, p. 674), pelo que fica aquém da Sprachlichkeit da experiência humana do mundo.

Conforme Gadamer, apenas a hermenêutica é capaz de fazer jus ao elemento especulativo da linguagem como "[...] realização de sentido, como acontecer do falar, do entender-se, do compreender. Essa realizaçáo é especulativa, na medida em que as possibilidades finitas da palavra estão submetidas ao sentido intencionado como uma orientação rumo ao infinito." (GADAMER 1999a, p. 679). Com efeito, o caráter especulativo da linguagem falada, que excede a própria dialética, reside numa "[...] unidade de sentido com a infinitude do não dito" (GADAMER 1999a, p. 680), por meio do que vem à fala uma relação com o todo do ser. Mais uma vez, a força viva da enunciação poética é o que paradigmaticamente deixa perceber a assimilação crítica da dialética. Por um lado, no poema como enunciado, a “[...] emancipação do que foi dito com respeito a toda opinião e vivência subjetiva constitui a realidade da palavra poética." (GADAMER 1999a, p. 680). Por outro lado, ao expressar como acontecer linguístico uma relação própria com o ser, a enunciação poética é especulativa por operar a proeza da contração do infinito no finito ${ }^{31}$.

\section{À Guisa DE ConClusấo}

Este artigo não teve uma pretensão de modo nenhum exaustiva. Quando muito, sua função foi apenas preliminar. Nosso objetivo foi mostrar que, a despeito muitas vezes da recepção de Hegel pelos filósofos do século $\mathrm{XX}$, seu pensamento tem ainda surpreendentes potenciais heurísticos para a história da filosofia, isto é, pode ainda facultar uma compreensão abrangente das linhas de força do debate filosófico contemporâneo. Em nosso caso, minha hipótese interpretativa consiste em que há, a partir de uma leitura de elementos do pensamento hegeliano que se conectam ao problema da linguagem, a possibilidade de buscar na dialética hegeliana elementos que promovem ao menos uma transição entre essas que me parecem ser as mais fundamentais correntes da reflexão filosófica sobre a linguagem, produzidas nos séculos XIX e XX, mas também desdobradas no século XXI, a saber: a concepção semântico-

\footnotetext{
31 "O poema, que logrou ser obra e criação, não é ideal, mas é espírito reanimado a partir da vida infinita ... se abre um mundo divino e humano ... não copia uma realidade que já é ... mas representa o novo aspecto de um mundo novo no âmbito imaginário da invenção poética." (GADAMER, 1999a, p. 681).
} 
pragmática de linguagem e a concepção hermenêutica de linguagem. Creio, como tentei demonstrar acima, que aquilo que favorece essa comunicação é a maneira como Hegel pensa a relação entre intersubjetividade e objetividade.

A questão da articulação entre objetividade e intersubjetividade é um problema de vital importância, na filosofia pós-wittgensteiniana da linguagem, particularmente sob a perspectiva das relaçóes entre semântica e pragmática ${ }^{32}$. Ao derivar de sua relativizaçáo da ênfase tradicional sobre o papel descritivo ou representacional das sentenças (WITTGENSTEIN, 1984, 1, p. 23-24) a tese de que essa função constatativa dos proferimentos se acha possibilitada por determinadas circunstâncias pragmáticas, isto é, elementos que dizem respeito à relação dos falantes com os signos (WITTGENSTEIN, 1984, p. 25-27), Wittgenstein prepara uma tese que vai ser muito influente sobre os expoentes da tradição pragmática, em especial, por Austin, a saber: a unidade fundamental entre semântica e pragmática, entre conteúdo proposicional e força ilocucionária, quer dizer, a tese de que referência e predicação somente são possíveis como partes integrantes de um ato ilocucionário.

Austin modificou substancialmente suas concepções, já ao longo das preleçóes que deram origem a How to do things with words, tornando prescindível a distinção entre proferimentos constatativos e performativos e assimilando seu significado à concepção mais abrangente de ato de fala. A partir desse ensejo, ele faz interessantes consideraçóes em torno da dimensão intersubjetiva da validade objetiva. Austin pretende, antes de tudo, mostrar que a expectativa verificacionista de que a validação veritativa de declaraçóes é absolutamente objetiva e constitui uma severa simplificação das coisas, pois as declaraçóes estão

\footnotetext{
${ }^{32}$ No início das Investigações Filosóficas, Wittgenstein vincula uma das diretrizes da "[...] visão agostiniana da linguagem”, segundo a qual "[...] sentenças são combinaçóes de nomes”, a decorrências emblemáticas. A única função da linguagem seria representar a realidade, as palavras se refeririam aos objetos e as frases descreveriam suas concatenaçóes (WITTGENSTEIN, 1984, 1, p. 237), uma defesa da função puramente descritiva das sentenças, de uma ênfase na função representacional ou descritivista da linguagem (WITTGENSTEIN, 1984, 1, p. 250). Com sua tese do significado como uso (WITTGENSTEIN, 1984, 1, p 262), a qual articula os problemas do significado e da compreensão, ele sustenta uma concepção pragmática de linguagem para a qual a comunicação e apreensão do sentido estáo incontornavelmente associadas ao aferimento de performances apropriadas a regras, aferimento cujo critério é a própria utilização da linguagem por uma comunidade linguística. Eis por que a discussáo da compreensão do sentido e do significado, como contrapartida de performances apropriadas, serve à sustentação das importantes posições segundo as quais compreender sentenças ou palavras significa compreender uma linguagem (WITTGENSTEIN, 1984, 1, p. 344), isto é, engajar-se numa prática comunitária (WITTGENSTEIN, 1984, 1, p. 345) regida por regularidades (WITTGENSTEIN, 1984, 1, p. 345) que sedimentam a normatividade de uma forma de vida (WITTGENSTEIN, 1984, 1, p. 356).
} 
frequentemente limitadas, na apreciação objetiva de sua verdade ou falsidade, às condiçóes limites e equívocas (AUSTIN, 1975, p. 145)

Essa concepção da verdade, em sua dimensão pragmática, permite a Austin um interessante exercício de relativização de sua distinção original. O proferimento constatativo consistia numa abstração das demais dimensóes do ato de fala, além do recurso a uma noção de verdade como correspondência que abstraía do componente ilocucionário (AUSTIN, 1975, p. 145-146). $\mathrm{O}$ performativo era uma abstração da dimensão de correspondência aos fatos, a partir da qual se erige o conteúdo proposicional (AUSTIN, 1975, p. 146). O autor envereda, entâo, por um fio de pensamento, por assim dizer, hegeliano: as abstraçóes teóricas são compreendidas como polos num desenvolvimento histórico (AUSTIN, 1975, p. 146-147). Assim como para Hegel, o mais adequado para Austin, do ponto de vista de uma consideraçáo da práxis comunicativa, seria justamente a mediação entre intersubjetividade e objetividade, uma concepção mais abrangente da linguagem como atividade, como algo, no jargáo de Hegel, espiritual. Nesse sentido, a teoria dos atos de fala traz a vantagem de articular a perspectiva pragmática da relação intersubjetiva entre falante e ouvinte com a perspectiva semântica da relação objetiva da linguagem ao mundo (HABERMAS, 2004, p. 8).

Se entendermos essa "mediação" no sentido propriamente dialético de uma articulação que convive com a preservação da plena autonomia dos polos, é forçoso reconhecer que, apesar de criticar a proposta de Brandom como repaginação da recaída de Hegel no idealismo objetivo, na "[...] assimilação da objetividade da experiência à intersubjetividade do entendimento mútuo" (HABERMAS, 2004, p. 15), Habermas considera ainda potenciais inovadores para a filosofia teórica, na argumentação hegeliana, ao menos enquanto esta for concebida como uma genuína dialética entre intersubjetividade e objetividade. Não fosse por isso, Habermas não teria feito deste o seu ponto de partida para uma intervenção contemporânea: a relativização, seguindo Dummett, da abstração do objetivo comunicacional em relação à função representacional, e da abstração da função representativa em relação ao objetivo comunicativo, defendendo a recíproca pressuposição das funçóes comunicativa e representacional (HABERMAS, 2004, p. 10-11).

Por outro lado, se Hegel radicaliza a relação kantiana entre pretensôes de validade objetiva e intersubjetividade, num sentido em que essa dinâmica se torna mais claramente estruturada linguisticamente, é verdade também que tal ligação não tem sido pertinente apenas no ambiente analítico. Gadamer 
defenderá uma relativização da verticalidade da semântica (objetividade) na horizontalidade da hermenêutica (intersubjetividade do diálogo), sob a alegação de que, estando a semântica presa à percepção da linguagem como composta de signos, os quais são instrumentos de que lançamos mão com o objetivo de nos comunicarmos, ela está aquém da experiência vital da língua onde vivemos, isto é, onde o que queremos comunicar só pode ser conhecido na forma da linguagem (GADAMER, 1999b, p. 209). Essa horizontalidade da linguagem, na qual se reúnem originariamente, para Gadamer, o eu e o mundo, corresponde, tendo em vista sua reclamada finitude e historicidade (GADAMER, 1999a, 600) - apesar da proximidade "metodológica" à mediação dialética do conceito, denunciada pela reconsideração do spekulativer Satz (ver HEGEL, 1970, 3, p. 58) (GADAMER, 1999a, p. 602-603) -, a uma estrutura especulativa do meio linguístico, a uma estrutura ontológica universal, que preside a constituição fundamental de tudo aquilo a que a compreensão pode se voltar, o que o leva a estabelecer que "[...] ser que pode ser compreendido é linguagem." (GADAMER, 1999a, p. 612). Essa "virada hermenêutica da ontologia”, embasada no modo especulativo da linguagem, em seu significado ontológico universal (GADAMER, 1999a, p. 613) e na tese de que a constituição especulativa do ser que subjaz à hermenêutica tem a mesma amplitude universal que a razão e a linguagem (GADAMER, 1999a, p. 615), faz da linguagem não só "[...] medium da experiência hermenêutica" (GADAMER, 1999a, p. 497), mas também - e por isso mesmo - a própria estruturação da experiência do mundo (GADAMER, 1999a, p. 589).

Finalmente, mesmo quando não se trata de hermenêutica tornada ontologia - quando, portanto, é o caso de uma assimilação crítica (APEL, 2000b) (HABERMAS, 1987) -, certa herança hegeliana pode ser percebida, ainda que a intersubjetividade não seja mais pensada no sentido ontológicohermenêutico do $\lambda$ oyos platônico, mas pragmático. Apel sugere que a filosofia contemporânea da linguagem deveria recuperar, diante da diversidade de suas orientaçôes, uma lição hegeliana: "[...] a formação filosófica de conceitos, na era das ciências particulares, precisa fundar-se não apenas sobre a abstração metódica do "entendimento", mas também sobre a retrogradação (metódica?) das abstraçôes do intelecto, constitutivas do objeto e obtidas por meio da "razáo". (APEL, 2000b, p. 376). Tal "conceito filosófico de linguagem", um conceito "transcendental-hermenêutico", refratário ao estranhamento heideggeriano entre filosofia e ciências (APEL, 2000b, 377), seria o único expediente capaz de tornar criticamente inteligíveis as tematizaçôes linguísticas metódico-abstrativas feitas pelas ciências, e estaria apto a mostrar, numa lembrança à articulação hegeliana 
entre intersubjetividade e objetividade, que “[...] as determinaçôes da linguagem feitas a partir de sua função designativa e comunicativa não eram falsas, mas filosoficamente insuficientes." (APEL, 2000b, p. 378-379). Habermas assinala, por sua vez, que a "[...] hermenêutica filosófica desconhece o direito autônomo da função cognitiva da linguagem", e "[...] não considera a possibilidade de uma interação entre o a priori de sentido da linguagem e o resultado de processos intramundanos de aprendizado" (HABERMAS, 2004, p. 81). Por outro lado, a filosofia analítica, mesmo quando náo se precipita na primazia do a priori de sentido constatada no Wittgenstein tardio (HABERMAS, 2004, p. 82) e reconhece a autonomia da função cognitiva (HABERMAS, 2004, p. 81), apresenta uma considerável inépcia para a Zeitdiagnose (HABERMAS, 2004, p. 95). Eis por que Habermas, para quem Hegel constitui o ponto de partida de uma modernidade que faz de si mesma Zeitdiagnose (HABERMAS, 1985, capítulos I e II), diante das aporias de uma crítica totalizante da razão (HABERMAS, 1985), na intenção de dar continuidade à teoria materialista da sociedade, através de uma teoria do agir comunicativo que diferencia comunicação de discurso, socialização individualizadora de razão procedimental, "[...] fazendo justiça ao sentido autônomo social-evolucionário de processos de aprendizagem intramundanos" (HABERMAS, 2004, p. 94-95), encontra acolhida no resgate, antecipado por Apel, de uma intuição hegeliana: "[...] uma dialética entre a abertura ao mundo e processos intramundanos de aprendizagem." (HABERMAS, 2004, p. 96).

LIMA, Erick. Between the pragmatic language and the philosophical hermeneutics: Hegel and the challenges of a structure of experience language. Trans/form/açāo, Marília, v. 39, n. 3, p.59-86, Jul./Set., 2016.

\begin{abstract}
This paper attempts to examine Hegel's comprehension of language and evaluate its relation to some themes in contemporary philosophy. The main purpose consists in pointing out Hegel's attempt to account for the linguistic structure of experience. To begin with, I consider Hegel's comprehension of language in an epistemological context as an effort to ground intersubjective justification of objective validity. Then I discuss the relation between cognition and inferential metaphysics. Finally, after arguing that Hegel anticipates the tension between grammar and lexical historicity, I attempt to show how the connection between the ontological turn in hermeneutics and Hegel's idea of the "speculative sentence" leads to the experience of the unfinishedness of poetic meaning.
\end{abstract}

KEYWORDS: language, epistemology, G.W.F. Hegel, pragmatics, hermeneutics 


\section{REFERÊNCIAS}

APEL, K-O. Transformação da filosofia. V.2: o a priori da comunidade de comunicação. São Paulo: Loyola, 2000.

AUSTIN, J. How to do things with words. New York: Oxford University Press, 1975.

BERSTEIN, R. The pragmatic turn. Cambridge: Polity Press, 2010.

BRANDOM, R. Making it explicit. Cambridge: Harvard University Press, 1994.

. Tales of the mighty dead: historical essays in the metaphysics of intentionality. Cambridge: Harvard University Press, 2002.

FALKE, G. Begriffene geschichte: das historische substrat und die systematische anordnung der bewußtseinsgestalten in Hegels 'phänomenologie des geistes'. interpretation und kommentar. Berlin: Lukas, 1996.

HABERMAS, J. Arbeit und interaktion: bemerkungen zu Hegels Jenenser "philosophie des geites". In: GÖHLER, G. Frühe politische systeme. Frankfurt am Main: Ullstein, 1974.

. Dialética e hermenêutica. Porto Alegre: L\&PM, 1987.

. Verdade e justificação: ensaios filosóficos. São Paulo: Loyola, 2004.

HEGEL, G.W.F. Werke in 20 Bände. Frankfurt am Main: Suhrkamp, 1970.

. Jenaer systementwürfe I. Hamburg: Felix Meiner, 1986.

HOULGATE, S. Hegel, Nietzsche and the criticism of metaphysics. New York: Cambridge University Press, 1986.

HUME, D. Hume: an enquiry concerning human understanding: and other writings. Cambridge: Cambridge University Press, 2007. (Cambridge Texts in the History of Philosophy).

KAHLENBERG, T. Die Befreiung der Natur: natur und selbstbewusstsein in der philosophie Hegels. Hamburg: Felix Meiner, 1997.

KANT, I. Kants Werke: Akademie textausgabe. Berlin: Walter de Gruyter, 1968.

LAFONT, C. The linguistic turn in hermeneutic philosophy. Cambridge: The MIT Press, 1999.

McDOWELL, J. Having the world in view: essays on Kant, Hegel and Sellars. Cambridge: Harvard University Press, 2009.

. Mind and world. Cambridge: Harvard University Press, 1996.

NUZZO, A. Hegel and the analytic tradition. Continuum: New York, 2010.

OLIVEIRA, M. A. A reviravolta lingüistico-pragmática na filosofia contemporânea. São Paulo: Vozes, 2001. 
LIMA, E.

PINKARD, T. Hegel's phenomenology: the sociality of reason. Cambridge: Cambridge University Press, 1996.

PIPPIN, R. Hegel's practical philosophy: rational agency as ethical life. Cambridge: Cambridge University Press, 1989.

PLATÃO. Platonis Opera. Oxford: Oxford University Press: New York, 1995. V. 1. (Oxford Classical Texts).

RAJCHMAN, J. Post-analytic philosophy. New York: Columbia University Press, 1985.

REDDING, P. Analytic philosophy and the return of Hegelian thought. New York: Cambridge University Press, 2007.

ROCKMORE, T. Hegel, idealism, and analytic philosophy. New York: Yale University Press, 2005.

SELLARS, W. Empiricism and the philosophy of mind. Cambridge: Harvard University Press, 1997.

VERNON, J. Hegel's philosophy of language. New York: Continuum, 2007.

WITTGENSTEIN, L. Werkausgabe in 8 Bänden. Frankfurt: Suhrkamp, 1984.

Recebido em 18/12/2015

Aceito em 23/05/2016 